\title{
Seth et al. Scale of Perceived Social Support for Elderly
}

\author{
Neha Seth $^{1 *}$, T. B. Singh ${ }^{2}$, Mona Srivastava ${ }^{3}$
}

\section{ABSTRACT}

The purpose of the study was to develop a scale to assess the perceived social- support comprising of five components among elderly in India. These five components are overall life perception, emotional support, physical support, nutritional support and financial support. Sample comprised of 103 elderly people of age 60 years and above (63 male and 40 female) living in urban area of Varanasi. Single stage cluster sampling was used to select the respondents and pre-tested and structured scheduled method was employed for data collection. A self developed 64-items was introduced earlier and 57-items in the final scale. These items were assessed through 4 point Likert scale. Mean, Median, Standard deviation, higher and lower values etc. of total score were calculated. The reliability of the scale was calculated by administering Cronbach-alpha. The Gutman split-half coefficient was found 0.77 , indicating higher reliability of the test. Construct validity of the test was determined by finding coefficient of correlation between scores and reliability of the scores. It was found 0.98, showing highly validity.

Keywords: Perceived Social Support Scale, Elderly, Social Support

With rapidly aging populations in countries around the world, there is an increased interest globally in the welfare of the elderly. This includes a concern with both their physical and psychological well-being. One of the important issues has been the effect of social support among elderly. Social scientists have long been fascinated by attitudes and beliefs surrounding family relationships and their roles. They believe that high level of social support may represent main source of personal care and well-being (Litwin and Landau, 2000) and a protective factor in reducing both the vulnerability of older people and risk of elder mistreatment (Melchiorre et al. 2013). Family support helps each family to construct a solid foundation from which to foster the growth of its members. Concerning the elderly, social isolation and a low level of social support may be significant risk factors for elder abuse, mistreatment and depression (Acierno et al.

\footnotetext{
${ }^{1}$ Research Scholar, Community Medicine, IMS, BHU, Varanasi, India

${ }^{2}$ Professor, Community Medicine, IMS, BHU, Varanasi, India

${ }^{3}$ Associate Professor, Department of Psychiatry, IMS, BHU, Varanasi. India

*Responding Author

(C) 2016, N Seth, T Singh, M Srivastava; licensee IJIP. This is an Open Access Research distributed under the terms of the Creative Commons Attribution License (http://creativecommons.org/licenses/by/2.0), which permits unrestricted use, distribution, and reproduction in any Medium, provided the original work is properly cited.
} 


\section{Seth et al. Scale of Perceived Social Support for Elderly}

2010). In contrast, an adequate level of social support may represent one potential protective factor for elder mistreatment (Dong and Simon, 2010) but if we go in depth, perceived social support is more important than received social support (Wethington and Kessler, 1986). Perceived social support have a great impact on well-being and surely perceived social support significantly predicts well-being (Skok et al., 2006). Persons who perceived themselves as having high levels of social support had high levels of well-being (Schulz and Decker, 1985). Furthermore, the person who perceives cagh levels of available social support is optimistic and such individuals possess a strong sense of self efficacy, positive evaluation of self, low anxiety and positive expectations about social interactions.

India's population is rapidly ageing. The stark reality of the ageing scenario in India is that there are around 116 million elderly at present and the number is expected to increase around 330 million, constituting 19.4 percent of the total population, by 2050. (United Nations Population Fund, 2015) As per census of India 2011 age of 60 years and above is about $8.0 \%$ of total population. With increased mean life expectancy from 40 years in 1951 to 64 years at present, a person today has 20 years more likely to live than he would have 50 years back. In addition, the society is experiencing tremendous demographic and socioeconomic transformations and due to this transition (industrialization and urbanization); the expulsion of joint family to nuclear family can be seen effortlessly. Since traditionally dominated by a joint family culture, Indian society has stressed the value of children in the lives of their elderly parents and this change is not swallowed by them easily, resulting in multiple kinds of diseases added to elderly but still their problems are more psychological than physical. Furthermore, attitudes, values and treatment have been changing rapidly especially for elderly which causes some unbearable, unexpected and new forms of problems among elderly and lack of social support is one of those causes which are a foundation of many of the problems like emptiness, hollowness and many more. Yet family size, structure, and sense of familial responsibility are rapidly changing to reflect the arrival of a market economy and hence, the enactments of laws are introduced in favour of elderly population. Hence to assess perceived social- support comprising of five components among elderly in India, a perceived social support scale with 57 items was conceptualized.

\section{NEED OF THE STUDY}

Although there is a huge list of instrument available as measures of problems related to elderly and focusing on the content of support, some experts or researchers have renowned affect, affirmation, and aid as a types of support (Abbey et al., 1985), others have examined or identified esteem, social integration, tangible and informational support (Cutrona and Russell, 1990); and emotional, instrumental, informational and appraisal support (House, 1981). Although there is considerable overlap among these approaches, it is clear that some researchers make distinctions and others choose not to make. Moreover, different types of support from the same person tend to be highly inter-correlated (House and Kahn, 1985). No scale was found on perceived social support which includes five components as follows: overall life perception, 


\section{Seth et al. Scale of Perceived Social Support for Elderly}

emotional support, physical support, nutritional support and financial support or in other words they were not able to fulfill the objective.

The fact remains that in existing Indian version of scales to measure problems related to elderly, there were no suitable scale to measure perceived social support among elderly. So, the aim to establish this scale was to determine whether social support (perceived help from family, friends, neibours and significant others) was related to various selected dimensions in old age in India. Rather than argue for the complete dismissal of these self report instrument, it seems more practical to place greater emphasis on their careful constructions and evaluation and to establish firmly their reliability and validity. The present study outlines the development of a new instrument assessing overall perceived social support among elderly.

Ultimately, the applicability of this measure will be for all individuals aged 60 and above, regardless of gender, caste, and ethnicity etc.

\section{THE SCALE}

\section{Design}

The concept of attitude towards elderly utilized in the present study represents an attempt to measure perceived social support among elderly. For purpose of this study Perceived social support is defined as a subjective evaluation of resources received in a given situation and its felt appropriateness and satisfaction (Vaux 1990).

Since, the purpose of the study was to treat the scale as an attitude scale, Edward's (1957) guidelines, the process outlined by Worthington and Whittaker (2006) and the methodology used by Anshu et al. (2015) for constructing Likert-type attitudinal scale were selected as a design model. One important design consideration affected by this selection is scale length. Scale items are appropriately comprised of items which evoke affect or opinion rather than cognition. When each item in scale evokes an effective response towards some aspect of the attitudinal object, the total scale cumulatively and effectively samples the attitude toward the object. One design criterion for constructing the scale was to avoid cognitive or recall items and to require that they deal with opinion toward perceived social support of elderly. An additional requirement was that each item has the anticipated probability of evoking divided agreement and disagreement from subjects in a normal population. Another requirement was that the items should be fresh and not drawn from the traditional item pool. One design characteristic was to produce a scale which had a single -item style throughout and which would have as simple a scoring scheme as possible. Both these requirement were met by adopting the Likert-type attitude scale format. 


\section{DEVELOPMENT}

Keeping in mind the desired design characteristics, items pertaining to opinion with various aspects of perceived social support among elderly were generated. These items were written using clear, concise and readable language. Content for these items was suggested by the literature on elderly and by the senior author's experience in elder's view point, and discussion with elders and experts in general.

Sixty Seven suitable items were collected and framed into an initial version of the scale. Response categories were: strongly agree, somehow, strongly disagree and can't say. Five experienced judges from the field of psychology, sociology and psychiatry agreed completely for evaluation on the favorability and unfavorability of the items. They reviewed the scale items in terms of sentence formation, clarity and complexity of the statements, repetition of sentences, monotonous statements and fulfillment of objectives of scale construction. Worthington and Whittaker also advocates taking particular notes on the item's clarity, conciseness, reading level, face validity, content validity, and redundancy. In the light of the criticism and comments offered by the experts, three items were altogether dropped and five items were rewritten or modified. 64 items were thus selected for the attitude scale which showed 100 percent agreement among the judges as related to development of scale.

\section{THE PILOT STUDY}

An initial administration of the scale utilized 103 volunteer subjects ranging from age 60 and above. 61.2 percent of this initial group was males and 38.8 percent were females. Total score of this initial study group ranged from 145 to 254 . The mean was 195.4 and the standard deviation was 27.6. Eighty percent of the scores were indicative of satisfaction. The result was left skewed, with the majority of scores being high and indicative satisfaction. Item analysis of data obtained in this pilot study administration indicated that seven items were to be discarded.

\section{THE FINAL STUDY}

After an instrument is developed and its reliability and validity are established, its research practicality must also be demonstrated. One indication of its proper development should be that it will function appropriately when used as intended. So finally 57 items perceived social support scale was administered to a group of 103 elderly people- 63 male and 40 female living in different blocks of Varanasi. The score of each item ranged from 1-4. Result of this study indicated that, in general, items correlated well with the total scale, that there was a very high level of internal consistency, and that the scale involved multiple factors (life overall). 
Seth et al. Scale of Perceived Social Support for Elderly

\section{Cronbach's alpha reliability of the selected questions after item analysis}

\begin{tabular}{|c|c|c|}
\hline S.No. & Items & $\begin{array}{l}\text { Cronbach's } \\
\text { alpha }\end{array}$ \\
\hline 1. & आप खुद को वृध्दावस्था में सुरक्षित महसूस करते हैं। & 0.972 \\
\hline 2. & तनाव में होनें पर आपको तनावमुक्त होनें में मदद मिलती है। & 0.972 \\
\hline 3. & आपकी वर्तमान योग्यताओं व क्षमताओं को महत्व दिया जाता है। & 0.972 \\
\hline 4. & आप चीजों के प्रति आशावादी हैं। & 0.972 \\
\hline 5. & आप वृध्दावस्था को एक समस्या मानते हैं। & 0.976 \\
\hline 6. & आप खुद को अन्यों की अपेक्षा भाग्यशाली मानते हैं। & 0.972 \\
\hline 7. & आप अपने सम्बन्धों (सामाजिक एवं पारिवारिक) से संतुष्ट है। & 0.972 \\
\hline 8. & आप अपने आस-पास मित्रता और खुशी महसूस करते है। & 0.972 \\
\hline 9. & $\begin{array}{l}\text { आपके मित्रजन, परिवारजन या पड़ोसी जरुरत पड़ने पर सदैव आपकी सहायता } \\
\text { करते हैं। }\end{array}$ & 0.972 \\
\hline 10. & आपको लगता है कि आप अपने परिवार का हिस्सा हैं। & 0.972 \\
\hline 11. & आपको लगता है कि आपकी परवाह किसी को नहीं चाहे कुछ हो जाये। & 0.976 \\
\hline 12. & सभी लोग आपका इज्जत, आदर, एवं सम्मान करते हैं। & 0.972 \\
\hline 13. & आप जो कहते हैं, लोग उसे सुनते एवं समझते है। & 0.972 \\
\hline 14. & $\begin{array}{l}\text { आपको लगता है कि लोग अक्सर आपके लिए अपनी सीमाओं से बाहर जाकर } \\
\text { आपकी सहायता करते हैं। }\end{array}$ & 0.972 \\
\hline 15. & घर के लोग आपसे आपकी जरुरत दर्शाते हैं। & 0.972 \\
\hline 16. & $\begin{array}{l}\text { आपको लगता है कि वाकई परिवारजन आपकी मदद करना चाहते हैं या करते } \\
\text { है। }\end{array}$ & 0.972 \\
\hline 17. & अपनी परेशानियों का हल आप परिवार में ढूँढते हैं। & 0.972 \\
\hline 18. & आपको समय-समय पर लोग जरुरी सूचनाऐं देते रहते हैं। & 0.972 \\
\hline 19. & आपके फैसले को उचित सम्मान दिया जाता है। & 0.972 \\
\hline 20. & $\begin{array}{l}\text { आप अपनी इच्छा से सामाजिक /पारिवारिक लेन-देन करते हैं अथवा करने के } \\
\text { लिए स्वच्छंद हैं। }\end{array}$ & 0.972 \\
\hline 21. & $\begin{array}{l}\text { आपको लगता है कि आपके किसी भी प्रकार की समस्या में, कोई ना कोई है, } \\
\text { जो आगाह करता है अथवा मदद करता है। }\end{array}$ & 0.972 \\
\hline 22. & आप परिवार के बीच खुद को सुरक्षित महसूस करते हैं। & 0.972 \\
\hline 23. & आपको लगता है कि आपका शारीरिक स्वास्थ्य अच्छा है। & 0.973 \\
\hline 24. & आप खुद को ऊर्जावान महसूस करते हैं। & 0.973 \\
\hline 25. & $\begin{array}{l}\text { आपको लगता है कि यदि आप बिस्तर पर भी आ जायें, तो कोई है जो आपकी } \\
\text { सेवा करेगा / करता है। }\end{array}$ & 0.973 \\
\hline 26. & $\begin{array}{l}\text { आपको जब अपनी कमजोंरियों के लिए झुंझलाहट होती है, तो परिवारजन } \\
\text { आपको इसकी बारीकियां समझाते हैं। }\end{array}$ & 0.972 \\
\hline 27. & आपको लगता है कि परिवार द्वारा आपकी देख-भाल के लिए उचित प्रबन्ध हैं। & 0.972 \\
\hline 28. & $\begin{array}{l}\text { खाली समय में आप अपनी रुचि को पूरा करते हैं अथवा करने के लिए स्वच्छंद } \\
\text { हैं। }\end{array}$ & 0.973 \\
\hline
\end{tabular}

(c) The International Journal of Indian Psychology, ISSN 2348-5396 (e)| ISSN: 2349-3429 (p) | 141 
Seth et al. Scale of Perceived Social Support for Elderly

\begin{tabular}{|c|c|c|}
\hline S.No. & Items & $\begin{array}{l}\text { Cronbach's } \\
\text { alpha }\end{array}$ \\
\hline 29. & $\begin{array}{l}\text { आपको अपनी इच्छापूर्ति (पूजा-पाठ, कोई विशेष रुचि) के लिए समय मिल } \\
\text { जाता है। }\end{array}$ & 0.973 \\
\hline 30. & आप अपनी दिनचर्या से संतुष्ट हैं। & 0.972 \\
\hline 31. & $\begin{array}{l}\text { आपको किसी प्रकार की बाधा अथवा कोइ टिप्पणी नहीं करता आपकी दिनचर्या } \\
\text { को लेकर। }\end{array}$ & 0.975 \\
\hline 32. & $\begin{array}{l}\text { आपको लगता है कि आपके परिवार में कोई है, जिससे आप बिना झिझक के } \\
\text { अपनी निजी परेशानियाँ या समस्या जरुरत पड़ने पर बाँट सकते हैं। }\end{array}$ & 0.972 \\
\hline 33. & परिवारजन आपकी जरुरतों को लेकर जागरुक अथवा संवेदनशील हैं। & 0.972 \\
\hline 34. & $\begin{array}{l}\text { आप जब की अेकलापन या परेशानी महसूस करते हैं, परिवार का कोई सदस्य } \\
\text { जरुर आपके साथ होता है, आपको प्रोत्साहित करने के लिए। }\end{array}$ & 0.972 \\
\hline 35. & $\begin{array}{l}\text { परिवारजन आपको अहसास दिलाते है कि वे आपके लिए कितना कर } \\
\text { रहें/करते हैं। }\end{array}$ & 0.975 \\
\hline 36. & $\begin{array}{l}\text { आप नकारात्मक भावनाएँ (जैसे दु:खी मन, निराशा, घबराहट, उदासी) महसूस } \\
\text { करते हैं। }\end{array}$ & 0.976 \\
\hline 37. & आपसे परिवारजन हँसकर, प्यार से बात करते हैं। & 0.972 \\
\hline 38. & त्योहार अथवा विशेष मौकों पर आपको उचित सम्मान देते हैं। & 0.972 \\
\hline 39. & $\begin{array}{l}\text { सांस्कतिक कार्यक्कमों अथवा छोटे समारोहों (जैसे पार्टी, शादी विवाह, आदि) में } \\
\text { आपको परिवारजन स्वेच्छा से सम्मिलित करते हैं। }\end{array}$ & 0.972 \\
\hline 40. & $\begin{array}{l}\text { परिवारजन पारिवारिक समस्या या किसी मुद्दे पर आपसे आपकी राय लेते अथवा } \\
\text { आपको राय देते हैं। }\end{array}$ & 0.972 \\
\hline 41. & आपको लगता है कि परिवारजन आपके लिए समय जरुर निकालते हैं। & 0.972 \\
\hline 42. & आप कहीं भी घुमने जाने के लिए स्वच्छंद हैं। & 0.972 \\
\hline 43. & $\begin{array}{l}\text { परिवारजन कहीं भी आपको साथ ले जाते हैं अथवा साथ चलने के लिए पूछते } \\
\text { है / आग्रह करते हैं। }\end{array}$ & 0.972 \\
\hline 44. & आपको लगता है कि आपकी चिन्ता आपसे ज्यादा परिवार को है। & 0.972 \\
\hline 45. & आप परिवार के बीच भी खुद को अकेला महसूस करते हैं। & 0.976 \\
\hline 46. & आपको अपने परिवार पर गर्व है। & 0.972 \\
\hline 47. & $\begin{array}{l}\text { आपको लगता है कि परिवारजन दैनिक क्रियाओं को करने में आपकी सहायता } \\
\text { करते हैं। }\end{array}$ & 0.972 \\
\hline 48. & आप अपने खान-पान से संतुष्ट हैं। & 0.972 \\
\hline 49. & परिवारजन आपको पौष्टिक आहार एवं फल इत्यादि देते हैं। & 0.972 \\
\hline 50. & आपको लगता है कि परिवाजन आपकी साफ-सफाई का उचित ध्यान रखते हैं। & 0.972 \\
\hline 51. & परिवाजन आपकी पसंद (खाना-पीना, कपड़े, घूमना) का ध्यान रखते हैं। & 0.972 \\
\hline 52. & आपको लगता है कि परिवारजन आपकी पसंद को पूरा करते हैं। & 0.972 \\
\hline 53. & परिवार से पैसे-सम्बन्धित जो सहायता मिलती है, आप उससे संतुष्ट हैं। & 0.972 \\
\hline 54. & परिवारजन आपकी स्वास्थ्य सम्बन्धित खर्च उठाते हैं। & 0.974 \\
\hline 55. & परिवारजन आपकी यातायात सम्बन्धित खर्च उठाते हैं। & 0.974 \\
\hline
\end{tabular}

(c) The International Journal of Indian Psychology, ISSN 2348-5396 (e)| ISSN: 2349-3429 (p) | 142 
Seth et al. Scale of Perceived Social Support for Elderly

\begin{tabular}{|l|l|l|}
\hline S.No. & Items & $\begin{array}{l}\text { Cronbach's } \\
\text { alpha }\end{array}$ \\
\hline 56. & $\begin{array}{l}\text { परिवारजन आपको आवश्यकतानुसार डॉक्टर अथवा स्वास्थ्य विशेषज्ञ के पास ले } \\
\text { जाते हैं। }\end{array}$ & 0.972 \\
\hline 57. & $\begin{array}{l}\text { परिवारजन बिना कहे आपकी समस्या भाँप जाते हैं और उसे पूरा करने के लिए } \\
\text { तत्पर रहते हैं। }\end{array}$ & 0.972 \\
\hline
\end{tabular}

Reliability, Validity and other Statistical Analysis of PSSS

\begin{tabular}{|l|l|}
\hline Reliability & 0.77 \\
\hline Validity & 0.98 \\
\hline Mean & 195.4 \\
\hline Standard deviation & 27.6 \\
\hline Median & 209 \\
\hline Cronbach's alpha & 0.976 \\
\hline Minimum & 126 \\
\hline Maximum & 232 \\
\hline Low & $<180$ \\
\hline Medium & $181-218$ \\
\hline High & $>218$ \\
\hline
\end{tabular}

\section{SUMMARY AND CONCLUSIONS}

An instrument in the form of a Likert-type attitudinal scale was developed for the purpose of assessing perceived social support of elderly from age 60 and above. It was administered to a total of 103 subjects. Items had very high discrimination and the instrument proved to be of sufficient reliability and of high internal consistency.

\section{Acknowledgments}

The author appreciates all those who participated in the study and helped to facilitate the research process.

\section{Conflict of Interests}

The author declared no conflict of interests. 


\section{REFERENCES}

Abbey, A., Abramis, D. J., \& Caplan, R. D. (1985). Effects of different sources of social support and social conflict on emotional well-being. Basic and Applied Social Psychology, 6(2), 111-129.

Acierno, R., Hernandez, M.A., Amstadter, A.B., Resnick, H.S., Steve, K., Muzzy, W., \& Kilpatrick, D.G. (2010). Prevalence and correlates of emotional, physical, sexual, and financial abuse and potential neglect in the United States: The National Elder Mistreatment Study. American journal of public health, 100(2), 292-297

Chandramouli, C., \& General, R. (2011). Census of India.

Cutrona, C. E., \& Russell, D. W. (1990). Type of social support and specific stress: Toward a theory of optimal matching.

Dong, X., Beck, T., \& Simon, M.A. (2010). The associations of gender, depression and elder mistreatment in a community-dwelling Chinese population: the modifying effect of social support. Archives of gerontology and geriatrics, 50(2), 202-208.

Edwards, A.L. (1957). Techniques of Attitude Scale Construction. New York: AppletonCentury crofts

House, J. S. (1981). Work stress and social support.

House, J. S., Kahn, R. L., McLeod, J. D., \& Williams, D. (1985). Measures and concepts of social support.

Litwin, H., \& Landau, R. (2000). Social network type and social support among the old-old. Journal of Aging Studies, 14(2), 213-228

Melchiorre, M.G., Chiatti, C., Lamura, G., Torres-Gonzales, F., Stankunas, M., Lindert, J., Elisabeth, K.I., Barros, H., Macassa, G.,\& Soares, J.F. (2013). Social support, socioeconomic status, health and abuse among older people in seven European countries. PloS one, 8(1), 54856.

Schulz, R., \& Decker, S. (1985). Long-term adjustment to physical disability: the role of social support, perceived control, and self-blame. Journal of personality and social psychology, 48(5), 1162-1172

Shukla, A., Deodiya, S., \& Singh, T.B. (2013). Marriage Perception Scale (MPS): Development of a measure to assess unmarried adolescent's perception about marriage. Indian J. Prev. Soc. Med, 44(1-2), 55

Shukla, A., Deodiya, S., \& Singh, T.B. (2015). Shukla Marital Coping Scale (SMCS): Development of a measure to assess unmarried adolescent's perception about level of adjustment after marriage. International Journal of Indian Psychology, 44(1-2), 55

Skok, A., Harvey, D., \& Reddihough, D. (2006). Perceived stress, perceived social support, and wellbeing among mothers of school-aged children with cerebral palsy. Journal of Intellectual and Developmental Disability, 31(1), 53-57

United Nations Population Division (2015), World Population Ageing, New york.

Vaux, A. (1990). An ecological approach to understanding and facilitating social support. Journal of Social and Personal Relationships, 7(4), 507-518.

(C) The International Journal of Indian Psychology, ISSN 2348-5396 (e)| ISSN: 2349-3429 (p) | 144 


\section{Seth et al. Scale of Perceived Social Support for Elderly}

Wethington, E., \& Kessler, R.C. (1986). Perceived support, received support, and adjustment to stressful life events. Journal of Health and Social behavior, 27, 78-89

Worthington, R.L., \& Whittaker, T.A. 2006. Scale Development Research: A content analysis and recommendations for best practices. The Counseling Psychologist, 34, 806-838

How to cite this article: N Seth, T Singh, M Srivastava (2016), Seth et al. Scale of Perceived Social Support for Elderly, International Journal of Indian Psychology, Volume 3, Issue 4, No. 60, ISSN 2348-5396 (e), ISSN: 2349-3429 (p), DIP: 18.01.091/20160304, ISBN: 978-1-36526308-8 